\title{
How Female Executives Affect Firm Performance? A Multi-approach Perspective
}

\author{
Chang-zheng Zhang ${ }^{*}$, Qian Guo, Xin Mu \\ School of Economics \& Management, Xi' an University of Technology, China
}

Copyright $\bigcirc 2016$ by authors, all rights reserved. Authors agree that this article remains permanently open access under the terms of the Creative Commons Attribution License 4.0 international License

\begin{abstract}
In recently years, female executives all over the world have attracted the widespread concern of many scholars, and the relationship between female executives' participation in top executive teams and firm performance is found to be considerably complicated. This paper tries to clarify this relationship by adopting a multi-approach perspective. It finds that resource dependency theory, catfish effect theory and stakeholder theory regard female executives as the facilitators of improving firm performance; feminism theory and vase theory indicate that female executives would contribute less than their male peers; upper echelon theory demonstrates a contingent effect instead of a fixed effect as considering female executives' effect on firm performance; assimilation theory argues that effect of female executives on firm performance has no difference with that of male executives; principal-agent theory, social capital theory and human capital theory all simultaneously hold contradictory views of positive effect and negative effect of female executives on firm performance; and social cognition theory argues that female executives' effect on firm performance is positive or null.
\end{abstract}

Keywords Female Executives, Firm Performance, Multi-approach Perspective, Principal-agent Theory

\section{Introduction}

Fifteen year into the 21 st century, gender equality appears to be at the forefront of the global humanitarian agenda [1]. As an increasingly important management group, the roles of female executives in firms' operation are attracting more and more attention from the management, economic and psychological scholars all across the world. Gender diversity of top executives teams is a critical variable in corporate governance research that has taken the center stage to enrich the corporate life and to empower the economy [2]. The involvement of female executives is increasingly recognized as an important corporate governance mechanism that affects and even determines a company's financial outcomes [3], besides potentially enhancing or weakening the board governance quality and monitoring effectiveness [4]. Though objectively a large number of female executives have succeeded in creating amazing performance in running modern companies, there are still great disputes in the leadership effectiveness of female executives among different scholars according to the existing literature. In other word, the involvement of females in top executive teams whether improves firm performance or not has not reached a consensus.

A few studies have provides evidence that the involvement of female executives in strategic decision-making process has positive effect on firm performance [2]. For example, in the business world, Joecks, Pull and Vetter [5] have argued that the presence of a critical mass, i.e., when at least three or more women directors $(30 \%)$ are on board, is associated with better performance for a sample of Israeli Government Business Companies and German companies. For another example, Joy, Carter, Wagner and Narayana [6] have discovered a strong and positive relationship between the ratio of female executives on the corporate board and the firm's financial performance among a sample of fortune 500 companies. On the contrary, several studies argue that the existence of female executives would lead to worse firm performance [7]. For example, Adams and Ferreira [8] have found that a negative relationship exists between the ratio of female executives and company performance in the US, partially attributed to the over-monitoring role by female directors. In addition, the increase of the involvement of female executives in top executive teams may result in an obvious increase in the cost of decision-making, as well as the possibility of conflict within the top management team, which may weaken the financial performance of a company [9]. What is more, besides the above opposite views on the role of female executives in affecting firm performance, there are still some other studies indicating that female executives have no effect on firm performance in practice at all [10], or at least, it can be argued that the role of female executives is a contingent effect which depends on the characteristics of female executives themselves or the 
features of the firms and industries instead of a fixed effect.

Since the female executives' effect on firm performance has not been clarified to a good degree, it is an important theoretical issue to review, explain and further balance the different conclusions on the role of female executives in determining firm performance. According to the common opinion of much existing literature, such inconsistent views may derive from different sample choices, various construct measures, distinctive empirical model designs, and even inconsistent time windows of the existing research. However, we demonstrate that such differences probably and basically derive from the traditional adoption of a single theory perspective on this topic. Each theory related to the firm performance consequences of female executives holds its own perspective, while many other possible causal paths of female executives' firm consequences confirming to some alternative theoretical perspectives would co-function together. The co-determination results of such causal paths would lead to different results at a high possibility. Therefore, this paper tries to comprehensively investigate the determining mechanisms of female executives' performance consequences by adopting the multi-approach perspectives.

The research is of good originality in gender diversity literature. Though the consequences of female presence on boards of directors and executive teams were widely studied in human sciences and management sciences literature, in our knowledge, there is still no exhaustive manuscript treating so many different theoretical perspectives. In this regard, this paper adds a valuable contribution to the field of gender diversity research, and the output of this research is interesting for future research in the field and explains the different results existing in the gender diversity literature.

\section{Potential Role of Female Executives in Determining Firm Performance: Conceptual Model Based on Multi-approach Perspective}

According to our opinion, the potential causal paths of the relationship between female executives and firm performance respectively are built on the basis of at least eleven competing theoretical perspectives, which include principal-agent theory, human capital theory, feminism theory, resource dependency theory, social capital theory, catfish effect theory, stakeholder theory, assimilation theory, vase theory, social cognition theory and upper echelon theory. Among the eleven theoretical perspectives, feminism theory and assimilation theory are relatively the newer emerging perspectives, while the other nine perspectives are relatively more traditional ones.

This paper establishes a conceptual model based on the eleven theories, which is shown in Fig.1. In Fig.1, there are three circles. The theories in the left circle (i.e., the slim line circle) represent the perspective that female executives have a positive impact on corporate performance. The theories in the right circle (i.e., the dotted circle) hold the idea that the relationship between female executives and corporate performance is negative. The bottom circle (i.e., the bold circle) indicates the influence of female executives on corporate performance has no difference with that of male executives.

According to the Fig.1, it can be known that resource dependence theory, catfish effect theory and stakeholder theory hold the view that female executives can promote company performance positively; but feminist theory and vase theory think female executives will hinder the company's performance oppositely. Resource dependence theory mainly argues that female executives have very different knowledge resource, relationship resource and mind-set resource which would supplement the resource shortage of the top management teams completely composed of male executives and further improve firm performance[11][12]. Catfish effect theory determines that the involvement of female executives can not only stimulate the reasonable and moderate competition among the male executives due to certain natural psychological, social and physical mechanisms between different genders, but can induce the new insights and perspectives on decision-making processes, and therefore female executives play a positive role in firm running [13]. The stakeholder theory recognizes that the involvement of female executives can meet the expectations of most of the stakeholders of the companies better, which mainly include the government, the community, the public media, the non-profit organizations, the employees and even the other companies running as their partners, and thereby the images of the companies in the eyes of the stakeholders would be positive which naturally would be beneficial for the companies to receive support from the stakeholders [14] .

According to the Fig.1, we can conclude that from the perspective of assimilation theory, on the performance consequence of female executives, there is nothing special compared with that of male executives. The main opinion of assimilation theory is that the reason why the females can be selected as the top executives is they have been assimilated by their male peers[15].That is to say, only when the females act and think the same as the way the males do, can they have the opportunity to be promoted. Therefore, no matter the female executives or the male executives, both of them have the very similar think patterns and behavior patterns. In other word, there are no differences in what they perform when they act as the executives for females and males. 


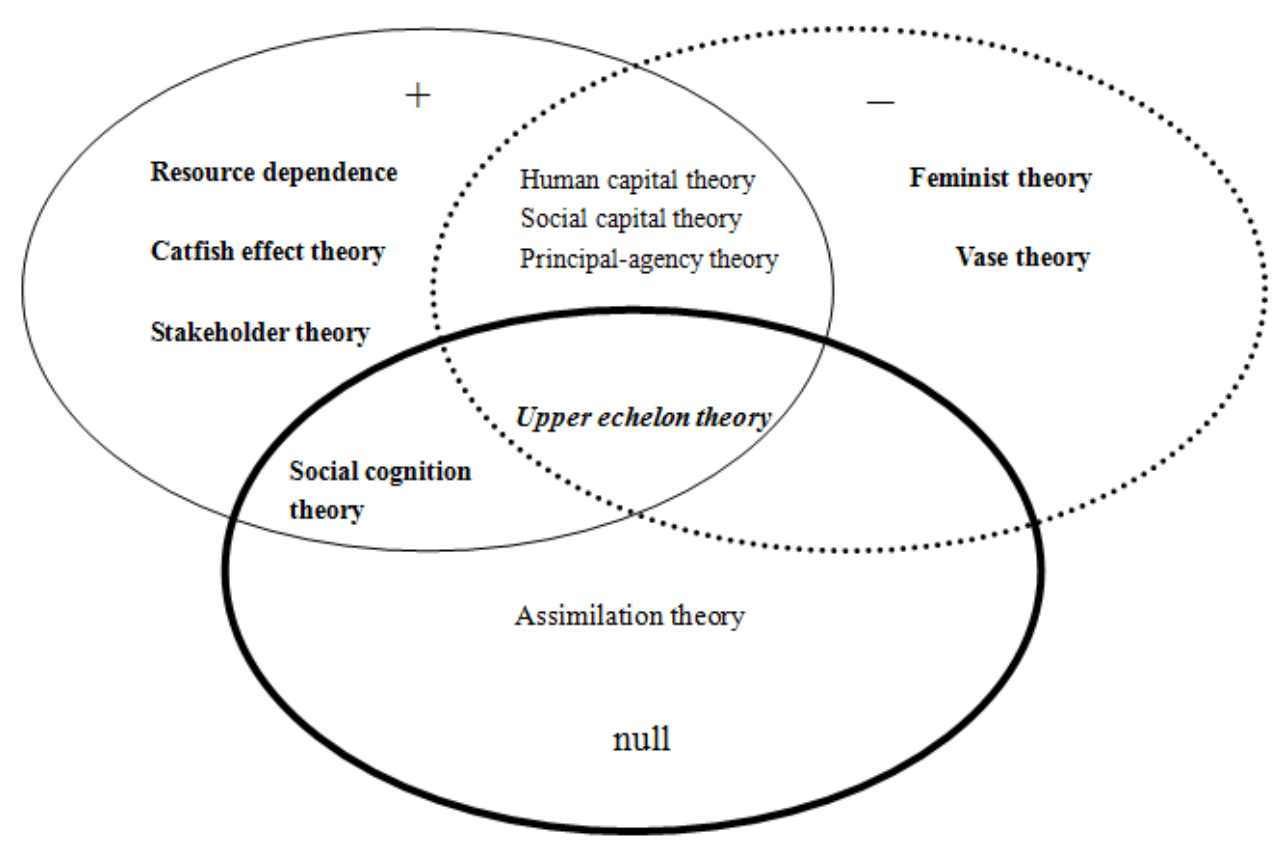

Figure 1. Conceptual model on the relationship between female executives and firm performance based on multi-approach perspective

However, there also exist some other theories which think the relationship between female executives and corporate performance is not simply absolute and fixed. For example, human capital theory, principal-agency theory and social capital theory take the point that female executives potentially have both positive and negative impacts on firm performance [16]. Scholars holding the perspective of human capital theory have different views on the performance consequence of female executives in firm running. A school of these scholars regard that female executives have higher quality of human capital than their male peers since only the most excellent female can be promoted as the executives, therefore the involvement of female executives in top management teams have positive effect on firm performance; however, another school of these scholars argue that in general female executives have lower quantity of human capital than their male peers, therefore, female executives would play the negative roles. Principal-agent theory, or more accurately, the expanded principal-agent theory claims that the presence of female executives can enhance the monitoring effectiveness of the corporate board which would be useful to mitigate the interest conflicts between top executives and shareholders. However, when the monitoring intensity derived from female executives is too strict for the free implementation of managerial discretion, the performance consequence of female executives would change into the negative one. Social capital theory reveals that female executives have very different social network with that of their male peers. Some of these scholars argue that female executives would build stronger social network by making full use of their gender advantage, while the other stream of these scholars claim that female executives have much smaller social network than their male peers since they have relatively less time and energy to build their social network. Accordingly, according to the perspective of social capital theory, female participation in the top executive teams potentially has both positive effect and negative effect on firm performance.

In Fig.1, social cognition theory regards that female executives have positive or null effect on firm performance. According to social cognition theory, when the proportion of female executives is below a certain level, the view of female executives cannot be paid attention to and treated seriously, and at this time, the role of female executives is almost null; however, when this proportion has reached a "majority" level, which is produced based on the unification of female executives and the confrontation among different male executive groups, the specialized knowledge, human capital, social capital and good views of female executives would have the chances to improve firm performance.

Besides the above theories from certain single trait of female executives, upper echelon theory, a more comprehensive theory simultaneously referring to multi-traits of female executives, even holds the point that the role of female executives in determining firm performance may be positive, negative, or null. Details about the different conclusions of different theories will be provided in the third section.

\section{Potential Role of Female Executives in Determining Firm Performance: Model Analysis}

\subsection{Role of Female Executives in Principal-agent Theory}

Principal-agent theory regards top executives as the self-interest agents who aim at pursuing their private benefits maximization, while viewing the shareholders and the board as the firm-benefiting principals who aim at 
monitoring top executives and preventing any potential activities that may deviate from firm value improvement. However, the effort in aligning the interest gap between top executives and the shareholders is rather hard to succeed due to the poor monitoring effectiveness on top executives. Not only the task characteristics of top executives can weaken the visibility of the executives' behavior and further lower the monitoring effectiveness of the board and shareholders, but the collusion behavior among top executives can damage the monitoring effectiveness to a larger degree [17].

In a pure historical viewpoint, principal-agent theory does not make a difference between male and female executives [18], and all of them are rational and self-interested agents, and all of them would have the same conflicts interest with the stakeholders (principals). However, with the evolution of principal-agent theory, the scholars of this school have gradually recognized that female executives usually act with higher ethical orientation than their male peers do by drawing on the views of gender diversity literature [19][20]. That is to say, the view point saying that women are less interested in the expropriation of firms' resources and perform the monitoring role better than their male peers comes from the dynamic development process of the principal-agent theory by combining and integrating the latest research contributions in gender diversity. In light of the newly-developed principal-agent theory, the monitoring role performed by female directors is an important corporate governance control mechanism, especially in countries where the external mechanisms are less well developed, for example, China. The gender composition of the board can affect the quality of this monitoring role and thus the financial performance of the firm. This is part of the "business case" for female participation on boards, though arguments may also be framed in terms of ethical considerations.

A few studies have confirmed such a view, among which the work of Tuan Nguyen et al [21] is of the typical importance. Their work investigates the relationship between board gender diversity and firm financial performance in the context of a transitional economy characterized by an underdeveloped corporate governance system. Using as ample of 120 publicly listed companies in Vietnam covering a 4-year period from 2008 to 2011, it examines such relationship in a dynamic modeling framework and accordingly proves that board gender diversity appears to have a positive effect on firm performance. According to the further data analysis, this finding remains robust when alternative proxies for gender diversity are employed and is consistent with the perspectives of agency theory and resource dependence theory. Besides, the number of female directors in the boardroom also matters, supporting the view that if female board representation affects firm outcomes, this effect is more pronounced when the number of female directors increases. Similar to this logic, many other studies have also found the positive link between gender diversity in the top executive teams and firm performance (or value)based both the US data and non-US data [22];[2];[23];[24];[25].

In light of this view, certain literature mainly adopting principal-agent theory has proved the existence of female in top executives reduces the possibility of collusion behavior of top executives and further improves the internal monitoring intensity of top executives [8], and female executives appear to be tougher monitors/supervisors than male executives. Ferryman, Fernando and Parathyroid [26] also regard that the increased gender diversity in top management teams has been shown to enhance monitoring processes, and may be a viable substitute mechanism for the stronger corporate governance control. The work of Yu Liu, Zuo-bao Wei and Fei-xue Xie[27] implies that the gender diversity of the board has a positive relationship with firm performance, especially in the company which has relatively poorer governance. Any decision that probably damages firm performance or sets firm under the condition of too high risk will be reviewed by the female executives. Not only female executives themselves may reject such potential wrong or risky decisions, but they will provide more information on decision-making process to the board or shareholders than male executives. That is to say, in one side, female executives intend to enhance internal monitoring intensity among top executives; in the other side, female executives lower the degree of information asymmetry between the principals and agents. Therefore, from the perspective of principal-agent theory, female executives are usually viewed as the facilitators of firm performance by most scholars. For example, Carter, Betty and Gary [2] have found significant effect on firm value when there are females on the board.

However, even adopting the perspective of principal-agent theory, few studies have found the opposite evidence on the role of female executives. For example, Adams and Ferreira [8] have proved that though female executives can improve the quality of company's governance by strengthening the intensity of monitoring in the board, too strict monitoring and intervention behavior derived from female executives would damage firm financial performance to a heavy degree. That is to say, the role of female executives in determining firm performance is negative. Female executives potentially have both positive and negative impacts on firm performance in the interpretation of principal-agent theory. 


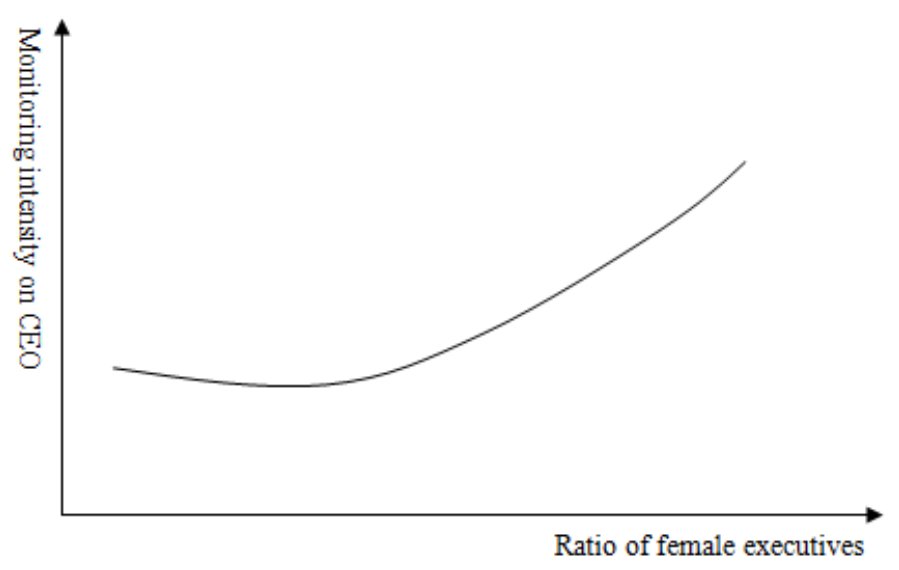

Figure 2. Role of female executives in principal-agent theory

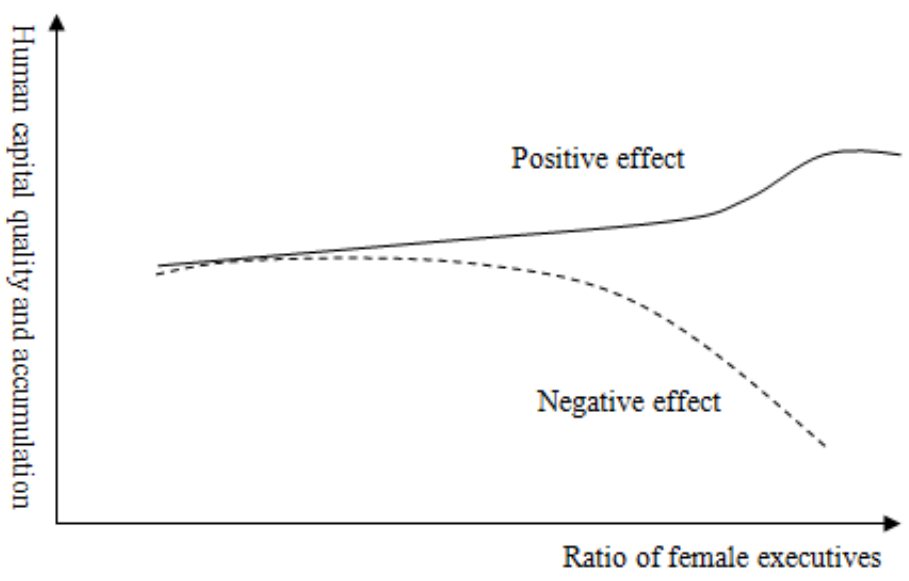

Figure 3. Role of female executives in human capital theory

\subsection{Role of Female Executives in Human Capital Theory}

Human capital theory argues that human capital has stronger effect than physical capital on economic growth in the macro level and firm growth in the micro level. Human capital comes from education and career experience. In real business world, males take the dominant status for promotion decisions in the workplace. For females, it is much harder to get promotion opportunities than males even they hold the-same qualifications. A professional ceiling for females exists widely. Under such a condition, females who want to be top executives must have higher human capital than their male competitors. Smith and Verner's results [29] show that the positive effects of females in top management strongly depend on the qualifications of female executives. Since female executives are of richer human capital than male peers in general, the involvement of females in top executives has positive effect on firm performance.

It is worth to point out that we only discuss the level of human capital of female executives, while the nature of human capital of female executives is ignored. In fact, even in the same level of human capital, female executives' human capital structure in nature is very different from that of male executives, since there are critical distinctiveness in mindsets, thinking pattern and decision-making favor between females and males. Facing the ever-changing environment, highly diverse human capital is needed for dealing with more and more uncertainties. The nature of female human capital would provide more innovative insights and ideas for running a firm than just male executives [30][31]. For example, Sodded and Ross [32] have indicated that the benefits of female representation in top management are increasing in the innovation intensity of a firm's strategies, even firms without any significant emphasis on innovation would not experience impaired performance as a result of female representation in top management. Kesner [33] considers that female executives can bring unique human capital to the board. Therefore, human capital theory indicates that the role of female executives in determining firm performance is positive by improving the total human capital level and enriching the human capital structure of top executives.

However, As Evans and Diekman (2009) [34] indicate that the acquisition of human capital can be limited where females are assigned to career paths that are considered more confirming to their stereotypical traits such as feeling support [35]. In this case, female executives will get the appointed work which is considered to be fit for the traits of the female' stereotype instead of the critical work which 
will contribute more to firm performance, and further restrain the accumulation of female executives' human capital which will make the negative influence on firm performance. Female executives are considered into some certain types of jobs, mostly auxiliary and secondary works which have little opportunity for getting to the top. A1986 Wall Street Journal survey has found "The highest ranking women in most industries are in non-operating areas such as personnel, public relations, or, occasionally, finance specialties that seldom lead to the most powerful top-management posts". Additionally, a lack of access to developmentally relevant role experiences, for example, line role, can seriously retard and delay female career development [36]. Hence, human capital theory holds the point that there are both positive and negative relationship between female executives and firm performance.

\subsection{Role of Female Executives in Feminism Theory}

Feminist theory tries to understand the nature of inequality and focuses on the so-called "gender politics, power relations and sexuality". While generally providing a critique of social relations, much of feminist theory also focuses on analyzing gender inequality, and improving the promotion of female' srights and interests [37]. Mainstream of feminism theory argues that the discrimination, exploitation and oppression against the group of females should be eliminated by improving and guaranteeing females' rights and chances of receiving higher education, participating election equally, acquiring promotion opportunities fairly and getting compensation reasonably.

Scholars who are interested in feminism theory mainly hold two branches of this theory in order to investigate the role of female executives in determining firm performance, i.e., liberal feminist theory and social feminist theory. Liberal feminist theory points out that because females usually face discrimination when they receive education and acquire critical business skills, the final obvious result is that males are more suitable for taking the higher positions as top executives. Sex discrimination is pervasive in the survey by Korn/Ferry International, where female executives have to answer the greatest hinder in their career development. The most popular answer was the gender (40\%) [38]. Eagly [39] has established a mixed picture for contemporary female leadership, in which female leaders are often associated with successful business organizations, but they simultaneously face challenges as leaders that males do not face, especially in the settings where female leaders are nontraditional. They are manifestations of gender relations that have changed greatly yet have not arrived at equality between the genders. Therefore, according to the view of liberal feminist theory, female executives would bring negative effect to firm performance
[40]. Social feminism theory regards that due to the different division of labor between females and males during the socialization process, females are endowed more responsibilities of caring for children and family, while males take more responsibilities of getting a job and earning money. Under such a division of labor, female executives commonly spend more energy and time into dealing with homework while reducing the time and energy in work. For example, Alowaihan's [41] empirical study finds that, in Kuwait, women who have married or have kids will reduce work hours, and certainly it will have some negative effect on firm performance. Therefore, in the light of social feminism theory, female executives will contribute less than their male peers.

In a word, no matter in the liberal feminist theory or social feminism theory, they all reveal that the role of female executives in determining firm performance is negative, and the critical distinguish between the two of them is described as follows: the former is because of the discrimination, females always don't have the critical business skills, so they will have a negative effect on firm performance; while the latter is that due to the different division of labor, females have to spend more time in homework while reducing the time and energy in working, so they would have a bad performance effect in company.

\subsection{Role of Female Executives in Resource Dependency Theory}

Resource dependency theory argues that the running of a firm needs all kinds of resources, while such resources cannot be totally owned by the company itself. On the one hand, the development of firm demands resources as many as possible; on the other hand, a firm has very limited resources itself. Therefore, it is natural that there is a gap between resource demand and supply for a developing company. In order to deal with such a gap, top executives have to enhance information exchange and communication with each other. Compared with male executives, female executives have some special advantages in interpersonal communication and teamwork [42]. Krishnan and Park [43] indicate that female executives' management styles and strong personal relationships may enable females to enrich decision making within their top management teams and thereby improve overall performance. The features of carrying out manful actions with drive, ambition and sweep for male executives may bring companies forward successfully in a single, safe and static market, while facing more dynamic, diverse and complex market in global competition, cooperation and teamwork, which female executives are more good at, would be critical to reduce the resource dependency degree of firm development. 


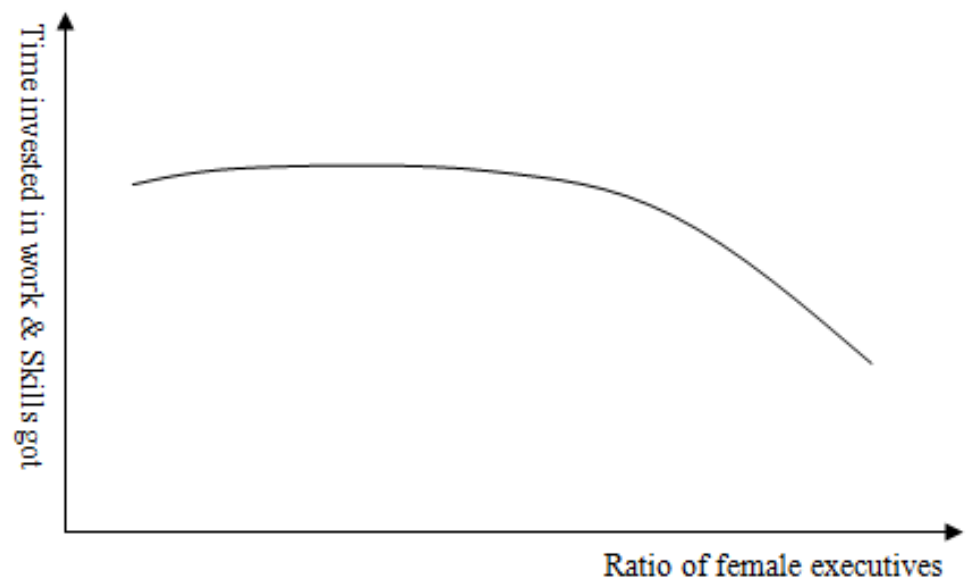

Figure4. Role of female executives in feminism theory

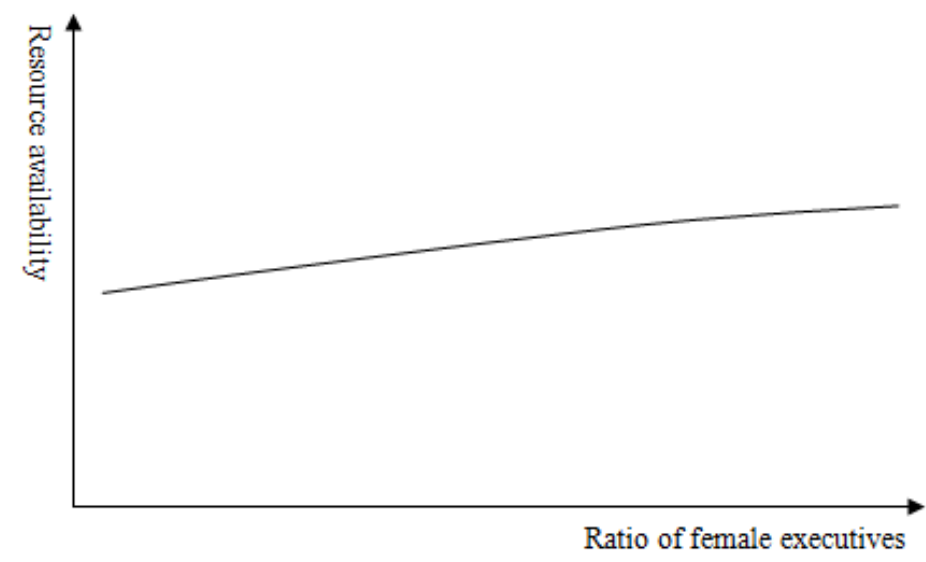

Figure5. Role of female executives in resource dependency theory

Besides the role of female executives in enriching the internal resources, female executives can also do good contributions to get external resources. During the communication process with the outside, differing from the tough style of the typical male executives, female executives can make full use of their gender advantage by adopting the softer communication style and thus strive for the external support, recognition and help more easily in a wider range. Therefore, companies which have more female executives will probably have more external resources. Since both the internal and external resources are helpful to the development of firm, resource dependency theory indicates that the role of female executives in determining firm performance is positive [44].

\subsection{Role of Female Executives in Social Capital Theory}

The central premise of social capital theory is that social networks have great value. Social capital refers to the collective value of all "social networks", i.e., who people know, and the inclinations that arise from these networks to do things for each other with the time goes by, i.e. norms of reciprocity. Bourdieu [45] has defined social capital as "the aggregate of the actual or potential resources which are linked to the possession of a durable network of more or less institutionalized relationships of mutual acquaintance or recognition". Social capital creates value for the people who are connected. An organization can benefit from the social capital of its members respectively through gaining external resources [46] and facilitating cohesiveness [47].

Research in social capital theory confirms the positive effect of female executives' performance consequences. For example, Ting Ren and Zheng Wang [48] support a positive relationship between the proportion of female participation and firm performance in Chinese privately owned companies, and females' social capital will further strengthen this positive effect. Social capital theory emphasizes that it is not just warm and cuddly feelings, but a wide variety of quite specific benefits that flow from the trust, reciprocity, information, and cooperation associated with social networks, while these terms are more closely related to females than males [49].

Differing from the positive view, some scholars who hold social capital theory find a negative relationship between female participation and firm performance. The inequitable division of domestic labor between males and females has consequences for the acquisition of social capital at work. Given that task completion must take priority over the socializing practice, Eagly and Carli [50] argue that those who can not put in extra time have far fewer chances to build social capital. In line with evidence that, on one hand, social capital is more essential to career advancement than 
skillful performance of traditional managerial tasks [51], and on the other hand, females who have an unequal share of domestic duties will be disadvantaged. Eagly and Carli [50] indicate that women always leave little time for socializing with their colleagues and building their professional networks. Especially it is true for the western females, since they have the larger house to sweep, the more children to bring up, the more family responsibilities to undertake, relative to the Chinese females. Even given sufficient time, women can find it is difficult to engage in and benefit from informal networking if they are a small minority. For females, breaking into such a network which is composed almost entirely of males is too hard. So, an insufficient social capital of female executives would result in a poor performance in their work, which would finally lead to a negative effect on firm value.

\subsection{Role of Female Executives in Catfish Effect Theory}

Catfish effect' is a term used in human resource management to describe how groups are motivated by the addition of a strong competitor, which is a method used to motivate the groups/teams so that each member feels strong competition, thus keeping up the competitiveness of the whole groups/teams. This term indicates a phenomenon that adding a strong, active, and most importantly, distinctive competitor to the existing relatively more stable workplace can sometimes motivate other employees to compete with more moderate intensity. This phenomenon can be explained by catfish effect theory coming from the practice of Norwegian fishermen, who usually put catfishes into containers with live sardines to keep them alive. Such a method keeps the sardines alive long enough to reach the market, where they can fetch a higher price than frozen sardines originally could. As for the running effectiveness of top executive teams, the catfish effect can be used to describe how new or distinctive female executives prompt the existing ones to work harder.

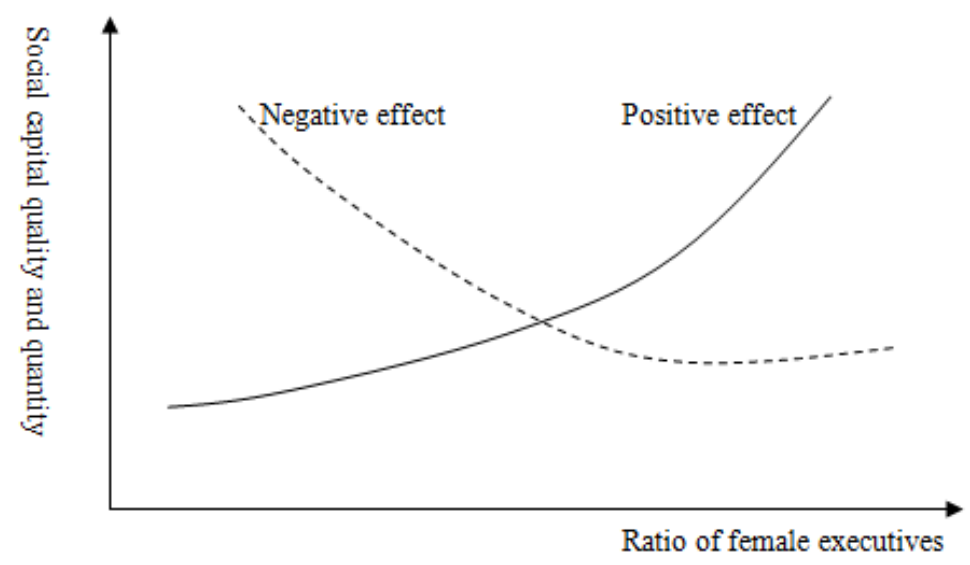

Figure 6. Role of female executives in social capital theory

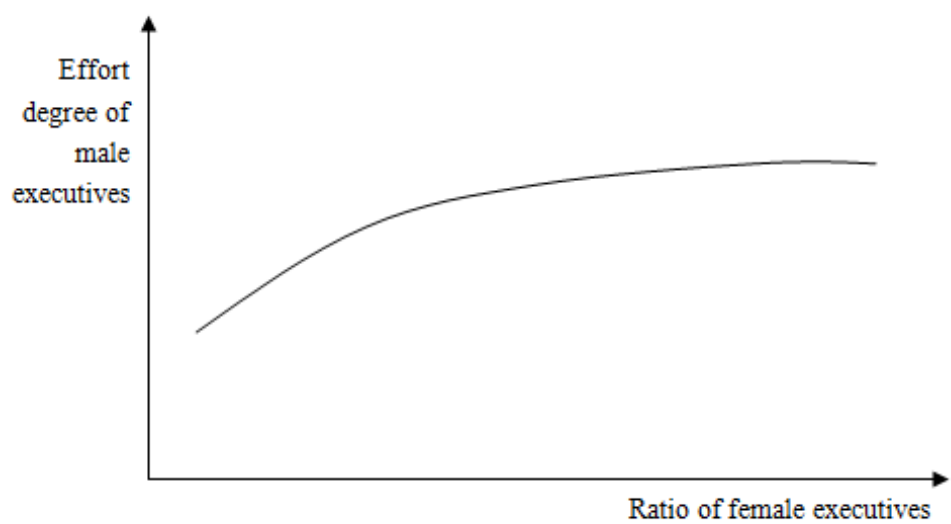

Figure 7. Role of female executives in catfish effect theory 
Supporters of the positive role of female executives in determining firm performance argue that female executives are the catfishes to the male executives as sardines, forcing the established male executives to offer better efforts and outcomes to avoid losing their face. Specifically, female executives are always mistaken as the people who generally show the shortage of energy and less involvement in job tasks since they have to balance their business and life. Ryanand Haslam [52] argue that during the process of the female climb to the top of the company ladder, they face greater challenges, and even if they arrive there, females are more likely to suffer greater scrutiny, criticism and discrimination than males, even when they perform exactly the same leadership roles as the males do. Consequently, in order to prove their own competence, female executives have to work harder than their male peers. As a result, such good performance of female executives beyond male executives' expectations will stimulate male executives in the top executive team, and male executives will work harder, reach higher effectiveness, and finally improve firm performance.

According the exiting literature in Physiology, Psychology and Brain Science, in most cases, male executives and female executives behave, feel, think, or respond in the different ways. For example, the male executives' brains are highly specialized, using specific parts of one hemisphere or the other to accomplish specific management (and decision-making) tasks, while the female executives' brains are more diffused utilizing significant portions of both hemispheres for a variety of management tasks. That means, firstly, male executives are more able to focus on some narrow issues and block out unrelated information and distractions, while female executives naturally see everyday things from a broader, 'big-picture' vantage point; secondly, male executives can narrowly focus their brains on specific management tasks or decision-making activities for long periods of time without tiring, while female executives are better equipped to divide their attention among multiple decision-making activities or management tasks; Third, male executives are able to separate information, stimulus, emotions, relationships, etc. into separate compartments in their brains, while female executives tend to link everything together. Besides, the most critical difference between female executives and male executives are that the thinking patterns and risk preferences of male executives in decision-making issues are relatively homogeneous and rigid, which pay more attention to logic reasoning than sensitive perception. In fact, a more suitable decision-making pattern should combine the two to a better degree. When female executives show their specific features and mindsets in decision-making process, male executives would recognize a new perspective in performing their decision-making discretion. No matter out of the issue of "face-saving" in the face of females, or out of the purpose of moving firm performance forward, male executives would adjust their behavioral patterns drawing on the advantages of female executives' think patterns and risk preferences. Here, the features of female executives' thinking patterns, skills, knowledge capital and specialized perspectives serve as the "Catfish" of male executives. Male executives would have to change themselves since they perceive the fresh competition pressure brought by the female executives. Therefore, in the light of catfish effect theory, female executives can affect firm performance positively by taking the role of "catfish" to male executives.

\subsection{Role of Female Executives in Stakeholder Theory}

The stakeholder theory argues that female executives are necessary to improve firm performance. The pressure of firms to appoint women as executives comes from a broad set of people, which includes shareholder activists, large institutional investors, politicians, public media and consumer groups, etc. In many researchers' opinions, an effective tool to explore this phenomenon and its consequences is called as stakeholder theory. The framework is now widely acknowledged in the management literature for its descriptive accuracy, instrumental power, and normative validity [53].

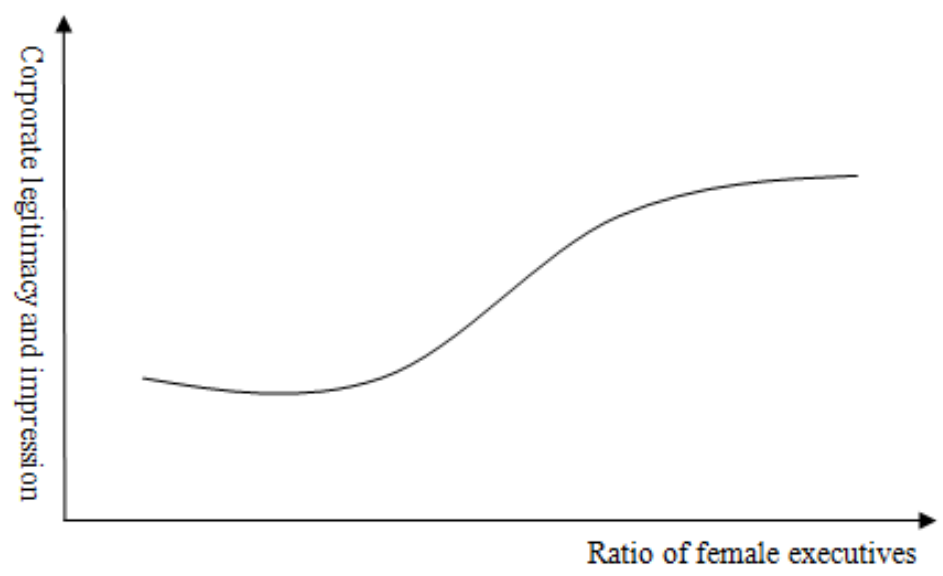

Figure 8. Role of female executives in stakeholder theory 
According to stakeholder theory, the executives serve as a linking mechanism between companies and the stakeholders, and it provides legitimacy and rationality to different stakeholders or groups within the society. While social pressure of appointing female as executives has increased in the past decade, this is more likely to have influenced companies which are more inclined to conform to societal expectations [11]. Jiekun Huang and Kisgen's study [54] conclude that investors also prefer company's strategical and tactic decisions made by firms with some female executives than firms with all males. When the outside world such as shareholder activists, large institutional investors and so on saw that there are female executives on company boards, they would regard that the diversity of company's values is pretty good. Any comprehensive investigation of the impact of providing legitimacy by female executives on corporate performance should not be limited to profitability, which is mostly concerned with shareholders' profit, but should include, at least society and market performance and the satisfaction of relevant stakeholders [11].

From this perspective, female executives might put forward the interests of employees and other stakeholders who have an impact on and are impacted by the company's performance [55]. In fact, female executives' participation would remain a sensible objective even if it does not necessarily lead to improved financial performance. Kahreh, Babania, Tive and Mirmehdi [56] aimed to examine the role of gender differences on the corporate social responsibility. Based on the data gathered and analyzed, it is demonstrated that there was not significance and meaningful differences between male and female in firm performance. Although there is not a significant relationship between female executives' participation and firm performance, females have more attention in dimensions of corporate social responsibility, they will attract the potential investors and even consumer groups, and further increase the possibility of firm performance's improvement. Hence, even if no significant relationship were found between female executives' participation and financial results, the promotion of females in firms can still be viewed as a good policy. To be sure, valuable social issues such as family life and flexible work arrangements are often given more importance in companies that attract female executives and board members [57]. Hence, some countries like Norway and German recently have enacted laws fostering the presence of women in business organizations.

\subsection{Role of Female Executives in Assimilation Theory}

Much work following the classical assimilation theory is based on the assumption that assimilation is a necessary part of the process of the upward mobility for female groups. This assumption is derived from the observation that at least some degree of assimilation is necessary in order to have full access to the opportunity of promotion for the females. For example, males always take a dominate status in a company, and females would act as males intentionally in order to acquire male executives' appreciation, and thus females would be assimilated by males gradually. Referring to the assimilation theory, when the role of new female executives is investigated, some scholars try to treat the assimilation of female executives as a social process to be explained rather than as a causal factor affecting outcomes.

Assimilation of female executives begins at the point of hire and is completed when the female executives become full contributors to the top executive team and are no longer considered outsiders in the team. For new female executives, the assimilation journey is realized through discoveries and new learning. New female executives are successful when, in spite of their expertise and experience, they begin to act as the way that the male executives do things and become a part of the original culture built by the male executives. Geiler and Renneboog [58] also put forward the point that both corporate performance and leadership seem to be more associated with masculine traits, while female leadership is often interpreted as not being congruent with females' gender role. The concept is called as the "romance of leadership". When assimilation is completed, a female executive has become a "male" executive.

Some survey has confirmed the above argumentation. For example, it is a common sense from the scholars in psychology that females are more risk aversion [59] .However, when we investigate the group of female executives, the result has changed a lot. One reason may be that male executives choose females who are very similar to them in psychological and physical natures as new executives [60], i.e., the ones who have higher risk preferences easily get the chance; The other reason may rely on that, even females with negative risk preference are lucky enough to be chosen as the executives, the assimilation process of female executives would change the original negative attitude of female executives to risk. Therefore, according to assimilation theory, the effect of female executives on firm performance has no difference with that of male executives.

\subsection{Role of Female Executives in Vase Theory}

Vase is a container which is usually made from ceramic or glass and has rather smooth appearance. Based on this, the vase theory mainly refers to something which can only be used for watching but have no practical use. In this part, we attempt to analyze the impact of female executives on company performance from this perspective.

In corporate governance filed, female executives are likely to be seen "useless" vase. First of all, they may be marginalized, do not have substantial power to participate in important decision-making, which makes the power of the female executives as a phantom and hinders them from making more contribution to company. Secondly, the reason why female executives are viewed as vases maybe they lack enough capacity and experience. Tharenou [61] points out that, compared with men, women have less work experience 
originally. And usually, a company rarely provides opportunities that are relevant to skills' training for women [62]. This will also directly lead to the fact that female executives would create lower performance for the company than the males do. Besides, extant studies have found females are afraid of competitive environment [63][64]. However, competition among corporate executives is highly fierce. In such environments, females will tend to avoid competition. Therefore, the performance created by female executives will naturally be lower than that created by male executives. Finally, Bilimoria' s study [65] shows that, in most companies, females mainly engaged in public affairs which are usually the company's non-core businesses, and the company also spends very few human, material and financial resources on them. Females are locked out of jobs in the "business mainstream", the route taken by CEOs and the board. But even when females can get the front-line jobs, it is not likely to be in a crucial part of the business or the type of jobs that can mark them as effective leaders. All these are not beneficial to female executives' work. Thus, according to the above four aspects, from the point of vase theory, we can conclude that female executives have a negative effect on corporate performance.

\subsection{Role of Female Executives in Social Cognition Theory}

Cognition refers to the collecting and integrating of both the internal and external information of a group to produce a context-specific response based on a set of decision rules. Similar to a general cognition, the so-called social cognition mainly refers to the neural processes that allow a person to adjust his/her behavior based on various social interactions. In a simple word, social cognition may be viewed as the different recognition of, or the adaptive response toward, social members. Many social behaviors such as cooperation behavior, territory behavior, assimilation behavior and even competition behavior are recognized as the products of social cognition. Following this logic, one special school of social cognition theory regards that generally in a group, most of the people will obey the principle of "the minority subordinating to the majority" [66][67], especially it is true when females act as the minority in a group. In this way, when there is a divergence or conflict during the process to make a decision for a group, they prefer to vote to choose the opinions of the majority and ignore the suggestions of the minority. Inside the group, the majority usually take the dominant status during the processes for determining the decision results of the group, the suggestions of the group development, and most of the critical things to a group. Therefore, it is rather easy for the majority, usually the male executives in reality, to defeat the minority or mitigate the real influence of the minority, usually the female executives in practice.

Elkinawya and Stater [68] have indicated that the larger firms and those with less female, where mostly the male executives have the dominated status in the boards, have less numbers of female executives and the probabilities of having female executives is also lower. That is to say, male executives usually play as the majority, so they have obvious advantages than female executives in the company. Though female executives may have the unique human capital, through which female executives can make a wise decision, it would still be ignored because they generally represent the minority and don't have the good opportunities to win in the fight against the male executives when there is an obvious divergence. The work of Yu Liu, Zuo-bao Wei and Fei-xue Xie[27] shows that the percentage of female executives has the significant and positive impact on firm performance measured by return on assets. The specific number of female executives is also important. They find that boards with three or more females have a stronger impact on firm performance compared with those with two or fewer females. Xian-Tao Huang [69] has found that the companies with a high proportion of female executives have a positive effect on firm performance, and companies with a lower proportion of female executives have a rather limited effect on firm performance. In this way, the role of female executives in determining firm performance depends on whether or not the number of female executives in a top executive team is the majority and/or whether or not the conception of group cognition is strong.

However, in the real business life, the number of females is almost always less than that of males in top executive team, and what is more, female executives usually tend to keep a consistent view with that of male executives because of the pressure from the other member of the group. In this way, it may restrain the positive effect of female executives in determining firm performance. But in certain situation where the group pressure for females is not so hard, female's unique thinking pattern would bring diversity to the decision-making processes, and further promote the firm performance with a certain possibility. That is to say, female executives not only may have a potential positive effect in determining firm performance, but may also have no effect on firm performance because the social cognition of the group may restrain them to a certain degree.

\subsection{Role of Female Executives in Upper Echelon Theory}

The above theories all explain the role of female executives in determining firm performance by their own unique perspectives. However, in a sense, upper echelon theory is the combination of them, which in fact adopts a much higher level perspective to clarify the relationship between female executives and firm performance. That is because all the theories except upper echelon theory indicate the points by analyzing one of the executives' characteristics, while upper echelon theory clarifies the point by analyzing almost all the traits that the top executive teams may have.

Upper echelon theory considers that the traits (or 
characteristics) of top executives, which mainly include knowledge, motives, attitudes, cognitive pattern and values, etc., determine their information acquisition and information explanation effectiveness in decision making process to a large degree [70]. In other word, executives' traits in psychological constructs affect their strategic choices and further determine firm behavior. Female executives' psychological natures, in general, are very different to male executives', no matter attitudes, cognitive patterns or values. The scholars holding upper echelon theory have carried out many studies in order to investigate the effect of gender diversity of top executive teams on firm performance. However, various results including positive effect, negative effect and even zero effect, all these have been supported to a greater or lesser degree. In a word, the contingent effect of female executives on firm performance in fact depends on the interactions among the various traits of female executives, firm characteristics and industry features.

It can be learned that, according to the research of upper echelon theory, the role of female executives in determining firm performance is affected by many other factors, while psychological features and physical features are only part of them. Therefore, it is a contingent effect instead of a fixed effect [71]. That is to say, the features of female executives are different from those of male executives', and they have various effects on firm performance which are contingent on many more factors, such as market type, industry features, enterprises development stage and firm size, etc. For example, female executives may reduce the success's possibility of start-ups, since they are not good at entrepreneurial behavior and risky actions [63][64]; while female executives may maintain the development of mature large enterprises, since such enterprises need more restraints, rules and standards instead of disruptive innovation. Marlinand Geiger [72] have found that the retail trade industry had a higher percentage of female executives than any of the other three industries (manufacturing, retail trade, finance/insurance, services industries) examined suggesting greater gender diversity in this industry, that is to say, female executives are good at in retail trade industry and further improve the firm performance. Yu Liu, Zuo-bao Wei and Fei-xue Xie [27] have documented that the relationship between female executives and firm performance depend on the type of company' owners. Specifically, if the owner is a legal person, it would be significant and positive relationship, while if it is the state-background owner, the effect would be not significant. Jiekun Huang and Kisgen [54] have examined the corporate financial and investment decisions made by female executives compared with those of the male executives. The results show that male executives intend undertake more acquisitions and issue debt more often than female executives do, and this evidence indicate the males are more overconfident in important company decision making compared with women.

\section{Conclusions}

Since the causal pattern of female executives' effect on firm performance has not be clarified to a good degree, it is an important thing to review, explain and further balance the different conclusions on the role of female executives in determining firm performance. The paper proposes that the potential causal paths of the relationship between female executives and firm performance are respectively built on the basis of eleven competing theoretical perspectives, which include principal-agent theory, human capital theory, feminism theory, resource dependency theory, social capital theory, catfish effect theory, stakeholder theory, assimilation theory, social cognition theory, and upper echelon theory. We can draw the conclusion that female executives will have different impacts on company performance from the perspectives of different theories.

From the perspective of principal-agent theory, female executives are viewed as the facilitators of firm performance by most scholars; Human capital theory indicates that the role of female executives in determining firm performance is positively realized by improving the total human capital level and enriching the human capital structure of the top executives, but also have a potential negative effect on firm performance because of a lack of access to the line job; In the light of feminism theory, female executives will contribute less than their male peers; Resource dependency theory indicates that the role of female executives in determining firm performance is positive; Social capital theory proposes both negative and positive effects of female executives on firm performance; In the light of catfish effect theory, female executives can affect firm performance positively by taking the role of "catfish" to male executives; Stakeholder theory proposes a positive effect of female executives on firm performance; According to assimilation theory, the effect of female executives on firm performance has no difference with that of male executives; Social cognition theory indicates that the role of female executives in determining firm performance is positive or null and the final result may rely on whether or not female executives confirm to the group pressure; According to the research of upper echelon theory, the role of female executives in determining firm performance is contingent on many other contextual factors.

The main contributions of this paper show as the following three points. First, it is the first study to investigate female executives' influence on firm performance from eleven various theoretical perspectives, which is helpful to reconcile different views on this topic and further clarify the nature of the role of female executives in determining firm performance more comprehensively. Second, besides the original attention from management scholars at present, the paper can draw more attention from psychology, sociology, politics and social psychology in the future which would improve the interdisciplinary research and thus shed better light on this topic. Third, the study theoretically provides multi-ways to 
improve the potential positive effect of female executives in improving firm performance which need the future empirical tests by taking the enterprises across the world as the research sample.

Each theory has its own theoretical assumptions on the characteristics of female executives and the features of the environment where female executives play their roles, which are actually culture-dependent, region-dependent, industry-dependent and even time-dependent. Only when the very situations investigated by the theory confirm to such assumptions, could the theoretical expectations really hold. However, the usual practical facts are that only parts of the assumptions of each theory are partially met, which would naturally result in that multi-paths for female executives' participation in determining firm performance held by various theoretical perspectives simultaneously function to different degree. That is why in reality we would find all kinds of female executives' performance consequences in the existing empirical literature. According to our knowledge, this paper is the first one which comprehensively investigates and discusses the influencing mechanisms of female executives' participation on firm performance from more than ten theories, and the output of this paper will provide the future research on female executives' participation and gender diversity with richer contributions and more comprehensive insights. In the future, the main objective of the research field of gender diversity in corporate governance should be focused on providing the practitioners with clear and systematic suggestions and/or tools on how to improve the positive performance consequences and simultaneously weaken the negative performance consequences of the female executives' participation by combining, comparing and even integrating the eleven theoretical perspectives comprehensively.

\section{Acknowledgements}

This research was supported by the National Social Science Foundation of PRC under Grant "15BGL109", the Scientific Research Foundation of Ministry of Education of the PRC in Humanities and Social Sciences under Grant"14YJA630089" and "13YJAZH123", and the Shaanxi Social Science Foundation under Grant "2014P04". Thanks to the suggestions and comments of the anonymous reviewers, whose great job improves the quality of this paper. However, all the faults and deficiencies belong to the authors.

\section{REFERENCES}

[1] Aparna Joshi, Brett Neely, Cynthia Emrich, and Gerard George. (2015). Gender Research in AMJ: AN Overview of Five Decades of Empirical Research and Calls to Action: Thematic Issue on Gender in Management Research. The
Academy of Management Journal, 58(5), 1459-1475.

[2] Bazeet olayemi Badru, Hauwa Daniyan Bagudu, Abdulmumini Baba Alfa, and Abdulmumini Baba Alfa. (2015). The Vital Role of Gender Diversity on Corporate Outcomes: The Need for Empirical Studies, Concerning Frontier Markets. Asian Journal of Finance and Accounting, 7(2), 183-200.

[3] Terjesen, S., Couto, E. B., and Francisco, P. M. (2015). Does the presence of independent and female directors impact firm performance? A multi-country study of board diversity. Journal of Management and Governance, January, 1-37. http://dx.doi.org/10.1007/s10997-014-9307-8.

[4] Capezio, A., and Mavisakalyan, A. (2015). Women in the boardroom and fraud: Evidence from Australia. Australian Journal of Management, July 23, http://dx.doi.org/10.1177/0 312896215579463 .

[5] Joecks, J., Pull, K., and Vetter, K. (2013). Gender diversity in the boardroom and firm performance: What exactly constitutes a "critical mass?". Journal of business ethics, 118 (1), 61-72. http://dx.doi.org/10.1007/s10551-012-1553-6.

[6] Joy, L., Carter, N. M., Wagner, H. M., and Narayanan, S. (2007). The bottom line: Corporate performance and women's representation on boards. Catalyst, 3 .

[7] Shrader, C. B., Blackburn, V. B., and Iles, P. (1997). Women in Management and firm financial performance: an explorative study, Journal of Managerial Issues, 9 (3), 355-372.

[8] Adams, R., and Ferreira, D. (2009). Women in the boardroom and their impact on governance and performance. Journal of Financial Economics, 94(2), 291- 309.

[9] Adams, R. B., Haan, J., Terjesen, S., and Ees, H. (2015). Board diversity: Moving the field forward. Corporate Governance: An International Review, 23(2), 77-82. http://dx.doi.org/10.1111/corg.12106.

[10] Kochan, T., Bezrukova, K., Ely, R., Jackson, S., Joshi, A., Jehn, K., Leonard, J., Levine, D., and Thomas, D. (2003). The Effects of Diversity on Business Performance: Report of the Diversity Network, Human Resource Management, 42 (1), 3-21.

[11] Mijntje Lückerath-Rovers. (2009). Female Directors on Corporate Boards Provide Legitimacy to a Company--A Resource Dependency Perspective. Management Online Review, June, 1-13. Available at SSRN:

http://ssrn.com/abstr act=1411693.

[12] Kenneth R. Ahern, and Amy Dittmar. (2011). The Changing of the Boards: The Impact on Firm Valuation of Mandated Female Board Representation. Quarterly Journal of Economics, 127(1), 137-197.

[13] Gröschl, S., Arcot, S. (2014). Female hospitality executives and their effects on firm performance, Tourism and Hospitality Research, 14: 143-151.

[14] Nick Bloom, Tobias Kretschmer, and John Van Reenen. (2011). Are family-friendly workplace practices a valuable firm resource? Strategic Management Journal, 32 (4), 343-367.

[15] Albrecht, James, Anders Björklund, and Susan Vroman, "Is there a glass ceiling in Sweden?", Journal of Labor 
Economics, 2003, 21 (1), 145-177.

[16] Female Participation in Top Management and Firm Performance, University of Maryland, Working Paper No. RHS-06-104.

[17] Tirole, J. (1986). Hierarchies and Bureaucracies: On the Role of Collusion in Organizations, Journal of Law, Economics, and Organization, 2, 181-214.

[18] Jensen M C, and Meckling W H. (1976). The theory of the firm: managerial behavior, agency costs, and ownership structure. Journal of Financial Economics, 3(4), 205-360.

[19] Cohen, G., and Kudryavtsev, A. (2011). Behavioral Biases in Economic and Financial Knowledge: Are They the Same for Men and Women? Advances in Management \& Applied Economics, 1(1), 15-52.

[20] David A. Carter, Frank D'Souza, Betty J. Simkins, and W. Gary Simpson. (2010). The Gender and Ethnic Diversity of US Boards and Board Committees and Firm Financial Performance. Corporate Governance: An International Review, 18(5), 396-414.

[21] Tuan Nguyen, Stuart Locke, and Krishna Reddy. (2015). Does boardroom gender diversity matter? Evidence from a transitional economy. International Review of Economics \& Finance, May, 37, 184-202.

[22] Daniel C.M. Low, Helen Roberts, Rosalind H. Whiting. (2015). Board gender diversity and firm performance: Empirical evidence from Hong Kong, South Korea, Malaysia and Singapore. Pacific-Basin Finance Journal, Volume 35, Part A, November, 381-401.

[23] Dutta, P., and Bose, S. (2006). Gender Diversity in the Boardroom and Financial Performance of Commercial Banks: Evidence from Bangladesh. The Cost and Management, 34(6), 70-74.

[24] Erhardt N. L., J. D. Werbel, C. B. Shrader. (2003). Board of Directors Diversity and Firm Financial Performance. Corporate Governance: An International Review, 11, 102-111.

[25] Kevin Campbell, and Antonio Mínguez-Vera. (2008). Gender Diversity in the Boardroom and Firm Financial Performance. Journal of Business Ethics, December, Volume 83, Issue 3, 435-451.

[26] Perryman, A., Fernando, G., and Tripathy, A. (2015). Do gender differences persist? An examination of gender diversity on firm performance, risk, and executive compensation. Journal of Business Research. 69(2), $579-586$

[27] Yu Liu, Zuo-bao Wei, and Feixue Xie. (2014). Do women directors improve firm performance in China? Journal of Corporate Finance, 28, 169-184.

[28] Carter, D., Simkins, B., and Simpson, G. (2003). Corporate Governance, Board Diversity, and Firm Value. Financial Review, 38, (3), 33-53.

[29] Smith, N., Smith, V., and Verner, M. (2006). Do women in top management affect firm performance? A panel study of 2500 Danish firms. International Journal of Productivity and Performance Management, 55(7), 569-593.

[30] Zelechowski, D., and Bilimoria, D. (2004). Characteristics of women and men corporate in side directors in the US. Corporate Governance: An International Review, 12(3): 337-342.

[31] Pelled, L. H., Eisenhardt, K. M., and Xin, K. R. (1999). Exploring the Black Box: An Analysis of Work Group Diversity, Conflict, and Performance. Administrative Science Quarterly, 44, 1-28.

[32] Dezso, C., and Ross. D. G. (2012). Dose female representation in top management improve firm performance? A panel data investigation. Strategic Management Journal, $33,1072-1089$

[33] Kesner, I. (1988). Directors' Characteristics and Committee Membership: An Investigation of Type, Occupation, Tenure, and Gender. Academy of Management Journal, 31, (1): 66-84.

[34] Evans, C. D., and Diekman, A. B. (2009). On motivated role selection: Gender beliefs, distant goals and career interest. Psychology of Women Quarterly, 33(3), 235-249.

[35] Lyness, S., and Thompson, D. E. (2000). Climbing the corporate ladder: Do female and male executives follow the same route? Journal of Applied Psychology, 85(1), 86-101.

[36] Fitzsimmons, T., Callan, V., and Neil Paulsen. (2013). Gender disparity in the C-suite: Do male and female CEOs differ in how they reached the top? The Leadership Quarterly. [Online]Available: http://dx.doi.org/10.1016/j. leaqua.2013.08.005

[37] Anil Kumar Mohapatra. 2009. Theory of Feminism and Tribal Women: An Empirical Study of Koraput, Mens Sana Monogr. Jan-Dec, 7(1), 80-92.

[38] Feminist Majority Foundation. (2014). Empowering Women in Business. Feminist Majority Foundation. [Online] available: http://www.feminist.org/research/business/ewb gl ass.html.

[39] Eagly, A. (2007). Female leadership advantage and disadvantage: resolving the contradictions. Psychology of Women Quarterly, 31, 1-12.

[40] Fischer, E. M., Reuber, A. R., and Dyke, L. S. (1993). A theoretical overview and extension of research on sex, gender, and entrepreneurship. Journal of business venturing, 8(2), 151-168.

[41] Alowaihan, A. K. (2004). Gender and Business Performance of Kuwaiti Small Firms: a Comparative Aroach. International Journal of Commerce \& Management, 14, (3/4), 69-82.

[42] Ping Zeng, and Qihong Wu. (2012). Impact of women's participation in top management team on enterprise performance: Review and prospect. Economic management, 34(1), 190-199.

[43] Krishnan, H., and Park, D. (2005). A few good women-on top management teams. Journal of Business Research, 58, $1712-1720$

[44] Hillman, A., and CannellaJr, A. (2007). Organizational Predictors of Women on Corporate Boards. Academy of Management Journal, 50, 941-952.

[45] Bourdieu, P. (1985). "The forms of capital", in Richardson, J.G. (Ed.), Handbook of Theory and Research for the 
Sociology of Education, Greenwood, New York, NY., 241-58.

[46] Hitt, M. A., Lee, H., and Yucel, E. (2002). The importance of social capital to the management of multinational enterprises: relational networks among Asian and western firms. Asia Pacific Journal of Management, Vol. 19, 353-72.

[47] Sirmon, D. G., Hitt, M. A., and Ireland, R. D. (2007). Managing firm resources in dynamic environments to create value: looking inside the black box. Academy of Management Review, 32, 273-92.

[48] Ting Ren, and Zheng Wang. (2010). Female participation in TMT and firm performance: evidence from Chinese private enterprises, Nankai Business Review, 2010, 13(5), 81-91.

[49] Kawachi I, Kennedy B, Lochner K, and Prothrow-Stith D. (1997). Social capital, income inequality and mortality. American Journal of Public Health, 87: 1491-1498.

[50] Eagly, A. H., and Carli, L. (2007). Through the labyrinth: The truth about how women become leaders. New York: Harvard Business School Press.

[51] Seibert, S. E., Kraimer, M. L., and Liden, R. C. (2001). A social capital theory of career success. Academy of Management Journal, 44(2), 219-237.

[52] Ryan, M., and Haslam, S. (2005). The Glass Cliff: Evidence That Women are Over-Represented in Precarious Leadership Positions. British Journal of Management, 16(2), 81-90.

[53] Donaldson, T., and Preston, L. E. (1995). The Stakeholder theory of the corporation: concepts, evidence and implications. Academy of Management Review 20(1), $65-91$.

[54] Jiekun Huang., and Kisgen, D. (2013). Gender and corporate finance: Are male executives overconfident relative to female executives?. Journal of Financial Economics, 108, 822-839.

[55] Kramer, V. W., Konrad, A. M., and Erkut, S. (2006). Critical Mass on Corporate Boards: Why Three or More Women Enhance Governance. Wellesley Centers for Women, Report No. WCW 11. Wellesley, MA: Wellesley Centers for Women

[56] Kahreh, M, S., Babania, A., Tive, M., and Mirmehdi, S. M. (2014). An examination to effects of Gender Differences on the Corporate Social Responsibility (CSR). Procedia-Social and Behavioral Sciences, 109, 664-668.

[57] Dallas, L. L. (2002). The New Managerialism and Diversity on Corporate Boards of Directors, Public Law and Legal Theory Working Paper 38 (Spring), University of San Diego School of Law (http:// ssrn.com/abstract_id = 313425), 30p.

[58] Geiler a, P., and Renneboog, L. (2015). Are female top managers really paid less? Journal of Corporate Finance, 35, 345-369.
[59] Vandegrift, D., and Brown, P. (2005). Gender differences in the use of high-variance strategies in tournament competition. The Journal of Socio-Economics, 34(6), 834-849.

[60] Xuguang Liu, and Weian Li. (2010). Study summary on female directors and corporate governance: Based perspective of boardroom diversity. Foreign Economics and Management, (4), 47-53

[61] Tharenou, P. (1995). Correlates of women's chief executive status: Comparisons with men chief executives and women top managers. Journal of Career Development, 21(3), 201-212.

[62] Oakley, J. G. (2000). Gender-based barriers to senior management positions: Understanding the scarcity of female CEOs. Journal of business ethics, 27(4), 321-334.

[63] Gneezy, U., Niederle, M., and Rustichini, A. (2003). Performance in competitive environments: Gender differences. Quarterly Journal of Economics-Cambridge Massachusetts, 118(3), 1049-1074.

[64] Niederle, M., and Vesterlund, L. (2007). Do Women Shy Away from Competition? Do Men Compete Too Much? Quarterly Journal of Economics, 122, 1067-1101.

[65] Bilimoria, D., and Piderit, S. K. (1994). Board committee membership: Effects of sex-based bias. Academy of management journal, 37(6), 1453-1477.

[66] Lent, R. W., Brown, S. D., and Hackett, G. (1994). Toward a unifying social cognitive theory of career and academic interest, choice, and performance. Journal of Vocational Behavior, 45(1), 79-122.

[67] Lent, R. W., Brown, S. D., and Hackett, G. (2000). Contextual barriers to career choice: A social cognitive analysis. Journal of Counseling Psychology, 47(1), 36-49.

[68] Elkinawya, S., and Stater, M. (2011). Gender differences in executive compensation: Variation with board gender composition and time. Journal of Economics and Business, $63,23-45$.

[69] Xian-tao Huang. (2014). Empirical study of the impact of female executives on corporate performance. Master Degree Thesis of Southwest Jiaotong University.

[70] K Nakatani, T Chuang, and D Zhou. (2009). An exploratory study of the extent of information technology adoption in SMEs: An application of upper echelon theory. Journal of Enterprise Information Management, 22, 183-196.

[71] Nielsen, S. (2010). Top Management Team Diversity: A Review of Theories and Methodologies. International Journal of Management Reviews, 12, (3), 301-316.

[72] Marlin, D., and Geiger, S. (2012). The Composition Of Corporate Boards Of Directors: Does Industry Matter? Journal of Business and Economics Research, 10 (3), $157-162$. 